\title{
ОСОБЛИВОСТІ КОНТРОЛЮ ЗНАНЬ СТУДЕНТІВ ПРИ ВИВЧЕННІ МЕДИЧНОЇ ХІМІЇ В УМОВАХ КРЕДИТНО-ТРАНСФЕРНОЇ СИСТЕМИ
}

\author{
ДВНЗ “Івано-Франківський національний медичний університет”
}

\section{FEATURES OF THE CONTROL OF STUDENTS' KNOWLEDGE IN THE STUDY OF MEDICAL CHEMISTRY IN A CREDIT-TRANSFER SYSTEM}

\author{
Ivano-Frankivsk National Medical University
}

\begin{abstract}
Згідно з принципами європейської кредитно-трансферної системи навчання поточний контроль знань на кафедрі біологічної і медичної хімії ІФНМУ здійснюється на кожному занятті. Для систематичного контролю і стимулювання регулярного навчання студентів на заняттях викладач оцінює всі форми роботи. Рейтингова система оцінювання успішності та визначення академічного рейтингу студентів забезпечує реалізацію дидактичного принципу свідомості студентів у навчанні, активізує навчальну роботу протягом семестру, спонукає студентів працювати систематично та самостійно. Дуже важливо формувати у студентів-медиків у процесі навчання системний підхід до розуміння функціонування організму в цілому і його взаємодію з навколишнім середовищем, розвивати в них логічне мислення, а також уміння аналізувати, синтезувати, порівнювати, прогнозувати.
\end{abstract}

In accordance with the European Credit-Transfer System the training current control knowledge at the Department of Biological and Medicinal Chemistry in Ivano-Frankivsk National Medical University is carried out at each session. For the systematic monitoring and promotion of regular education students in the classroom teacher evaluates all forms of work. The rating system evaluating progress and determining academic ranking of students, ensures the implementation of the principle of didactic mind students' learning, promotes academic work during the semester, encourages students to work systematically and independently. It is important to form medical students in learning systems approach to understanding the functioning of the whole organism and its interaction with the environment, they develop logical thinking and ability to analyze, to synthesize, to compare and to predict.

Вступ. В даний час все більш актуальною стає дискусія на тему підвищення якості вищої освіти як одного з найважливіших чинників забезпечення її ефективності в цілому. При цьому все більша увага приділяється впливу якості освіти на рівень створення професійної готовності випускника до майбутньої діяльності. Оцінка якості освіти має на увазі як безпосередню оцінку якості освітніх досягнень студентів, так і оцінку якості освітнього процесу [1]. В свою чергу, якість освіти насамперед залежить від умов навчання: наближення навчання до студента, стану матеріально-технічного та організаційно-методичного забезпечення навчального процесу, рівня впровадження новітніх технологій, кадрового потенціалу, стану впровадження в навчальний процес досягнень науки тощо. 3 іншого боку, процес змін у системі освіти, заданий Болонською декларацією, включає також введення нових механізмів і процедур контролю якості освітнього процесу [2].

(C) М. В. Карпець
Процес контролю - це одна 3 найбільш трудомістких і відповідальних операцій у навчанні, пов'язана з різними психологічними ситуаціями як для студентів, так і для викладача. 3 іншого боку, його правильна постановка, безсумнівно, сприяє поліпшенню якості підготовки фахівців. У більшості навчальних закладів вибір видів контролю (попередній, поточний, тематичний, підсумковий) і його форм (іспити, заліки, контрольні роботи, семінари тощо) залежать від мети, змісту, методів. Посилення уваги до проблеми контролю знань викликано не тільки бажанням визначити ступінь підготовленості студентів, але і вдосконаленням всієї системи навчання.

Об'єктивність системи контролю та оцінювання результатів може стимулювати навчальну діяльність студента, у протилежному разі - призведе до відсутності мотивацій до навчання. 3 іншого боку, $є$ проблема мети отримання позитивної оцінки студентами. Більшість першокурсників не 
повністю розуміє різницю між гарною успішністю i фундаментальними знаннями 3 дисципліни. Це вимагає від викладача, який працює із студентами молодших курсів, наполегливої праці з виховання у студентів прагнення до отримання насамперед змістовних знань.

Основна частина. На кафедрі біологічної та медичної хімії ІФНМУ відповідно до принципів кредитно-трансферної системи застосовується рейтингова система контролю, що дозволяє добиватись більш ритмічної роботи студентів протягом семестру, а також активує їх пізнавальну діяльність, стимулює творчу активність. Основними методами контролю знань, умінь та навичок студентів є: тестовий контроль, усне опитування, перевірка виконання самостійної позааудиторної роботи (СПР), виконання і захист лабораторної роботи.

Тестування використовується у всіх видах контролю і здійснюється як в аудиторній, так і позааудиторній роботі (виконання домашніх завдань), а також тестовий контроль використовується під час складання підсумкового модульного контролю. Застосування цього методу дає можливість в найбільш короткий термін одночасно перевірити засвоєння матеріалу всіма студентами групи, визначити напрямки для індивідуальної роботи з кожним. Крім того, згідно із основними положеннями кредитно-трансферної системи, в умовах скорочення аудиторних годин, більша увага студентів повинна приділятися самостійному вивченню матеріалу. Навчальний процес у ВНЗ набуває науково-пошукового характеру. Також значною мірою збільшується обсяг інформації для вивчення. 3 нашого досвіду можна стверджувати, що для студентів-першокурсників така система навчання є досить складною, що можна пояснити складністю їх адаптації до нових умов навчання, тому що в середній школі новий матеріал спочатку пояснюється на уроці, а потім подається на засвоєння вдома. Студенти першого курсу визнають, що однією з проблем у навчанні $€$ невміння самостійно опрацьовувати навчальний матеріал. Крім того, студенти, особливо молодших курсів, не вміють раціонально планувати свою навчальну діяльність, займатись самоосвітою; у них часто відсутня мотивація до навчання. Із цього випливає необхідність покращення та якісного удосконалення аудиторної та позааудиторної роботи студентів, а саме постійного контролю засвоєння набутих знань.

Медична хімія є фундаментальною наукою і вивчається протягом першого року навчання. Для студентів-першокурсників важко знайти мотивацію для вивчення дисципліни, оскільки вони ще не мають певних знань 3 анатомії людини, нормальної фізіології, медичної біології, гістології, а тим більше клінічних дисциплін. У зв'язку з цим, кожне заняття з хімічних дисциплін на кафедрі починається 3 мотиваційної характеристики теми, де студенти за підтримки викладача показують теоретичну та практичну значимість матеріалу даної теми, новизну навчального матеріалу, професійну направленість навчальної діяльності на занятті. Окрім того, для студентів проводяться консультації, які дають змогу студентам із викладачем розглянути незрозумілі питання, освоїти алгоритм розв’язку задач, оволодіти практичними навичками.

Програма $з$ медичної хімії поділена на 2 модулі, які є логічно завершеними частинами дисципліни. До підсумкового контролю допускаються студенти, які виконали всі види робіт, передбачені навчальною програмою, та при вивченні модуля набрали кількість балів, не меншу за мінімальну (60 балів). Це сума балів поточного контролю, який здійснюється під час проведення практичних занять [3].

Викладачі кафедри розробили банк тестових завдань I-II рівня складності з усіх тем практичних занять. Для перевірки вхідного рівня знань використовують тести I рівня, які забезпечують контроль на рівні впізнання раніше почутого чи прочитаного, на рівні загальних неконкретизованих, неглибоких уявлень про теоретичний зміст. Виходячи з цих вимог, це тести з одиничною вибірковою відповіддю: одна правильна відповідь вибирається з чотирьох - п’яти запропонованих, питання формулюється в межах теоретичного матеріалу підручника. Тести II рівня включають вирішення задач, розрахунків, складання схем реакцій, вибір методу корекції. Ці тести пропонуються студентам після опрацювання нового матеріалу та пояснення розв'язку задач викладачем, ними оцінюють кінцевий рівень знань.

Зрозуміло, що проектування тестів потребує значних витрат часу. Але розроблена викладачами система тестових завдань з певної навчальної теми у подальшому призводить до суттєвого скорочення часу на контроль за навчальною діяльністю студентів. Так, система тестових завдань, розроблених на кафедрі біологічної та медичної хімії ІФНМУ 3 курсу “Медична хімія” з усіх тем практичних занять, суттєво скоротила витрати навчального часу на перевірку поточного та модульного контролю. Викладач не має можливості протягом чотирьох занять перевірити відповідь від кожного студента 
на 30 запитань 3 дисципліни, а тестова програма дозволяє це зробити. Тому електронне тестування в такому випадку надає можливість оцінити всіх студентів і отримати об’ єктивні результати їх знань.

Для проведення модульного контролю розроблена нова система тестування а test 3.0, яка значно збільшила успішність. Перевагою даної програми $€$ те, що кожен студент може самостійно, в будьякий зручний для нього час, через мережу Інтернет протестуватися вдома без обмеження числа спроб. Після закінчення тестування можна проглянути детальний звіт з вказівкою набраного бала, правильних відповідей, власних відповідей.

Впровадження в медичну освіту системи тестових інтегрованих іспитів Крок 1, 2, 3 - це серйозний крок з удосконалення системи навчання. Підготовка студентів до цих іспитів вимагає значних зусиль і праці професорсько-викладацького складу. Вона повинна розпочинатись заздалегідь, а не безпосередньо перед іспитами. Для забезпечення цього процесу необхідна перебудова засобів контролю знань майбутніх фахівців, що вимагає створення на кожній кафедрі тестових завдань системи “Крок” для кожного практичного заняття. Враховуючи вимоги сьогодення, вони повинні бути включені в навчальні і навчально-методичні посібники, методичні розробки для студентів, що дає можливість підвищити ефективність самостійної підготовки майбутніх лікарів [4].

Результативність навчального процесу, у першу чергу, залежить від навчально-методичного забезпечення. Бібліотека університету майже повністю забезпечує студентів підручниками 3 дисципліни “Медична хімія”. Окрім того, на кафедрі пропо-

\section{Список літератури}

1. Місце тестування в системі моніторингу якості освіти Запорізького державного медичного університету / Ю. М. Колесник, Ю. М. Нерянов, В. А. Візір, О. В. Деміденко // Медична освіта. - 2012. - № 3. - С. 77-80.

2. Суліма $Є$. Невідкладні завдання системи вищої освіти на новому етапі Болонського процесу / Є. Суліма // Вища школа. - 2010. - № 1. - С. 5-13. нуються електронні версії підручників, методичні рекомендації до кожного практичного заняття. На сайті кафедри в повному обсязі міститься навчально-методичний матеріал для аудиторної, позааудиторної роботи, банк тестових завдань для підготовки до модуля. Кожний студент за бажанням може придбати друкований робочий зошит, який є досить зручним для підготовки студента до заняття. В ньому наведено тему, мету, актуальність, перелік питань для самостійної позааудиторної роботи, контрольні запитання, хід виконання лабораторної роботи. Викладач на початку заняття перевіряє виконання СПР у робочому зошиті, а в кінці заняття кожен студент захищає протокол лабораторної роботи, який повинен бути оформлений належним чином. Кожен етап роботи оцінюється, якщо студент належним чином не підготувався і в сумі за заняття отримав менше 6 балів, він повинен перескласти “негативну оцінку”. Тому наше завдання - навчити студентів працювати самостійно, використовуючи доступні джерела інформації. Крім того, активних студентів залучають до виконання наукових робіт на базі кафедри, вони беруть участь у предметній олімпіаді, презентують свої роботи на конференціях, конкурсах.

Висновки. Незважаючи на використання різних форм контролю студентів, організація навчальнопедагогічної діяльності і надалі потребує удосконалення та пошуку нових її форм. Перспективним напрямом є інтеграція міждисциплінарних зв’язків, особливо $з$ клінічними дисциплінами, що сприятиме розвитку клінічного мислення та слугуватиме мотиваційною базою для вивчення студентами дисципліни “Медична хімія”.

3. Карпець М. В. Модульний контроль - невід’ємна складова оцінки якості знань студентів / М. В. Карпець // Nowoczesna edukacja: filozofia, innowacja, doswiadczenie. - Lodz. - 2015. - № 2. - C. 18-20.

4. Про підготовку до впровадження системи ліцензійних державних інтегрованих перевідних і випускних іспитів у медичних вищих закладах освіти III-IV рівнів акредитації : наказ МОЗ України від 31.12.1996 р. № 396. 